\title{
Microbiological and parasitological contamination of hydroponic grown curly lettuce under different optimized nutrient solutions
}

\author{
Antonio Fernandes Monteiro Filho ${ }^{1}$, Carlos Alberto Vieira de Azevedo ${ }^{2 * 3}$, Márcia Rejane de Queiroz \\ Almeida Azevedo ${ }^{1}$, Josely Dantas Fernandes ${ }^{1}$, Élida Barbosa Correa ${ }^{1}$, Shirleyde Alves dos Santos ${ }^{1}$ \\ ${ }^{1}$ State University of Paraíba, Center of Environmental and Agrarian Sciences, Lagoa Seca, 58.117-000, Paraíba, Brazil \\ ${ }^{2}$ Federal University of Campina Grande, Academic Unit of Agricultural Engineering, Campina Grande, 58.429-140, \\ Paraíba, Brazil \\ ${ }^{3}$ Fellow of CNPq Research Productivity, level 1B, Brazil
}

*Corresponding author: cvieiradeazevedo@gmail.com

\begin{abstract}
Lettuce is the most widely consumed vegetable in the world; however, its sanitary quality is questioned during the production process. The objective of this research was to evaluate the microbiological and parasitological contamination of curly lettuce grown in a nutrient film technique (NFT) hydroponic system with different nutrient solutions. The experiment was conducted in randomized blocks with three replicates, and the treatments corresponded to four mineral solutions, and four organomineral solutions, totaling eight nutrient solutions. At harvest, samples formed by ten plants per plot were collected and analyzed for microbiological contamination (Escherichia coli, Salmonella spp., total coliforms and thermotolerant coliforms) and parasitological contamination (endoparasites). The results showed absence of contamination by E. coli and Salmonella spp. in all samples. Few lettuce samples exhibited presence of Entamoeba histolytica, eggs and larvae of Ancylostoma spp. Lettuce cultivated with mineral solutions of Furlani, and Castellane and Araújo and organomineral solution of Furlani were free from contamination.
\end{abstract}

Keywords: Lactuca sativa, L.; health quality; hydroponic.

Abbreviations: BM_mineral nutrient solution of Bernardes (1997); FM_mineral nutrient solution of Furlani (1995); CM_mineral nutrient solution of Castellane and Araújo (1994); UM_mineral nutrient solution of Ueda (1990); BO_modified nutrient solution of Bernardes (1997) ; FO_modified nutrient solution of Furlani (1995); CO_modified nutrient solution of Castellane and Araújo (1994); UO_modified nutrient solution of Ueda (1990); BIO1_biofertilizer used in the modified solution of Ueda (1990); BIO2_biofertilizer used in the modified solution of Castellane and Araújo (1994); BIO3_biofertilizer used in the modified solution of Furlani (1995); BIO4_biofertilizer used in the modified solution of Bernardes (1997); TH_cultivar Thaís; VA_cultivar Vanda; VE_cultivar Verônica; MPN_most probable number; NFT_Nutrient film technique.

Introduction

Among the vegetables, lettuce (Lactuca sativa, L.) is the most consumed worldwide and in Brazil (Moretti and Mattos, 2005; Filgueira, 2008). Its cultivation is concentrated close to metropolitan areas due to the short post-harvest lifespan (Henz and Suinaga, 2009).

Lettuce production in the Paraiba state is concentrated in the Brejo Paraibano microregion and the municipality of Lagoa Seca is one of the main producers of vegetables in the state. According to data of IBGE (2009), lettuce production in Paraíba in 2006 was estimated at 6,530 t. The sanitary quality of the lettuce produced in this municipality has been studied for years. Barros et al. (1999), evaluating irrigation water quality in vegetable crops, found that $88 \%$ of the samples contained fecal coliforms above the levels recommended by the CONAMA Resolution 357/2005, which established that waters intended for irrigation of crops that are consumed fresh must have a maximum of 200 fecal coliforms or $E$. coli in $100 \mathrm{~mL}$. The lettuce plants showed these indicators at concentrations much higher than the standard established by the National Health Surveillance Agency (ANVISA) Resolution RDC 12/2001, which limits to 100 fecal coliforms per gram of sample. Various studies conducted in supermarkets and open markets in Campina Grande city, considered as the main consuming center of vegetables produced in the municipality of Lagoa Seca, Paraiba, report high microbiological and parasitological contamination, which may be associated with the utilization of inputs (organic fertilizers) and contaminated irrigation water, besides inadequate handling of the product (Souto, 2005; Santos and Peixoto, 2007).

The sanitary control of vegetables is fundamental in all stages of production (from planting to harvest) and postharvest, because they are consumed fresh and, in case of inadequate conditions, may serve as a transmitter of pathogenic microorganisms that cause diseases like enteritis and anemia, such as bacteria, protozoa and helminths, among other pathogenic microorganisms of fecal origin (Itohan et al., 2011; Ferreira et al., 2013). 
Lettuce can be cultivated using the conventional technique (soil + mineral or organic fertilizer) or hydroponic technique. In the latter, plants are cultivated in the absence of soil, receiving through a balanced nutrient solution all the essential nutrients required for development. Comparing both techniques with respect to the microbiological contamination of vegetables, Santana et al. (2006), Rocha et al. (2008) and Dias and Gazzinelli (2014) found contamination originated from the organic, mineral and hydroponic system; however, it is important to point out that the sampling was performed in supermarkets and open markets, and it is not clear in which stage of the production chain the contamination occurred.

In the last years and beyond the sanitary perspective, the interest in foods produced with smaller amounts of synthetic fertilizers has increased (Finatto et al., 2013). The utilization of organomineral nutrient solutions formulated using a biofertilizer can be a viable alternative for hydroponic production. It is scientifically known that the contamination of vegetables irrigated with sewage effluents is influenced by the treatment received. According to Lima et al. (2005), an effluent from sewage treated in UASB reactor followed by polishing pond has satisfactory sanitary quality, while the utilization of sewage only decanted should be avoided in the irrigation of vegetables.

The utilization of organomineral solutions in hydroponic systems is still little studied; thus, information related to the sanitary quality is scarce, which led to the conduction of the present study aiming to evaluate, microbiologically and parasitologically, samples of curly lettuce cultivated in hydroponic system with mineral and organomineral nutrient solutions.

\section{Results and discussion}

\section{Contamination by total coliforms}

The results relative to the most probable number (MPN) of total coliforms found in hydroponic lettuce cultivated with mineral and modified nutrient solutions are presented in Table 1.

Only with the use of the modified solution of Castellane and Araújo (1994) (CO), in the third sampling, there was contamination with total coliforms above $100 \mathrm{MPN} \mathrm{g}^{-1}$. This result may be associated with the handling or even with a cross-contamination, because when the MPN (most probable number) of total coliforms found in the nutrient solutions (Table 2), which were higher than 1,600 MPN 100 $\mathrm{mL}^{-1}$, in all modified nutrient solutions, is compared with that observed in the lettuce samples, there is a considerable reduction of contamination. This same behavior also occurred with the utilization of mineral solutions, except for the mineral solution of Castellane and Araújo (1994) (CM) in the third sampling, which showed contamination of 39 MPN $\mathrm{g}^{-1}$ in the lettuce, higher than that observed in the CM stock solution, equal to $21 \mathrm{MPN} 100 \mathrm{~mL}^{-1}$.

The low values of total coliform contamination found in the lettuce samples (Table 1) indicate that the hydroponic system can be efficient regarding the lower microbiological contamination of the crops produced in this system, because the nutrient solutions do not come into contact with plant shoots, as frequently occurs in organic or conventional production systems. It becomes evident that the irrigation water or fertilizer mode of application is of great importance in the process of contamination of vegetables.

Studies have demonstrated that the types of fertilizer and planting system influence the sanitary quality of the vegetable. Tavella et al. (2012), applying biofertilizers with dilution above $3 \%$, through the leaves, observed high levels of lettuce contamination by total coliforms (460 MPN g ${ }^{-1}$ ). Similar results were also obtained by Arbos et al. (2010), evaluating lettuce fertilized with organic fertilizer, who found contamination above $240 \mathrm{MPN} \mathrm{g}^{-1}$, and Baumgartner et al. (2007), using reuse water from fish and pig farming applied via drip irrigation ( $2400 \mathrm{MPN} \mathrm{g}^{-1}$ ).

Cases of contamination by total coliforms have also been reported in hydroponic cultivation. Santana et al. (2006) observed, in $100 \%$ of the hydroponic lettuce samples from the market of Salvador, values of total coliforms above 100 MPN $\mathrm{g}^{-1}$. Santos et al. (2010), analyzing samples of hydroponic lettuce from the market of Botucatu, SP, found contamination by fecal coliforms with MPN of $4.6 \times 10^{4}$. Although the contamination of lettuce from hydroponic system is related to post-harvest, some cases have been reported, such as Tonet et al. (2011), who found contamination above $1100 \mathrm{MPN} \mathrm{g}^{-1}$ in $30 \%$ of the evaluated samples in lettuce harvested in hydroponic system.

Despite the lack of federal standards for levels of total coliforms in vegetables, the utilization of this parameter as indicator of sanitary conditions points, in cases of high count of these microorganisms, to a probable contamination of the food during the production, poor cleanings and sanitizations. In the present study, the use of hydroponic system minimized these problems. This highest contamination observed in the third count with the utilization of $\mathrm{CM}$ and $\mathrm{CO}$ solutions was due to the incorrect sanitation practices in the activities of both conduction and harvest, which corroborates Hoolyer et al. (2009).

\section{Contamination by thermotolerant coliforms}

Regarding the occurrence of thermotolerant coliforms (45 ${ }^{\circ} \mathrm{C}$ ), the values found in the curly lettuce ranged from 1.8 to 6.8 MPN g ${ }^{-1}$ (Table 3). These results are considered as satisfactory because the National Health Surveillance Agency establishes, for fresh vegetables, the standard of maximum presence of $100 \mathrm{MPN} \mathrm{g}^{-1}$ (ANVISA, 2001).

The $95 \%$ confidence intervals provide the information that, in at least $95 \%$ of the times, the actual concentration of the target microorganism may be included in the confidence interval calculated for each arrangement of positive tubes. This means that, with the utilization of the solutions $\mathrm{BO}$ and $\mathrm{CO}$, both in the third sampling, the maximum count of coliforms at 45 으 can reach up to $17 \mathrm{MPN} 100 \mathrm{~g}^{-1}$, which is 488.23\% lower than that established by ANVISA (2001), which confirms the good sanitary quality of the produced lettuce, regardless of the utilized nutrient solution.

The values of coliforms at 45 을 found in the nutrient solutions, as well as in the tank water used to prepare the solutions, are below the value established by the Resolution $357 / 2005$ (CONAMA, 2005), which is $200 \mathrm{MPN} 100 \mathrm{~mL}^{-1}$. This fact contributed to the low count of thermotolerant coliforms found in the evaluated lettuce samples. 
Table 1. Most probable number (MPN) of total coliforms in curly lettuce.

\begin{tabular}{|c|c|c|c|c|c|}
\hline \multirow{2}{*}{ Nutrient solutions } & \multirow{2}{*}{ Samples } & \multirow{2}{*}{ Combination of Tubes + } & \multirow{2}{*}{ MPN $100 \mathrm{~g}^{-1}$} & \multicolumn{2}{|c|}{ Confidence interval (95\%) } \\
\hline & & & & Minimum & Maximum \\
\hline & 1 & $1-1-0$ & 4.0 & 0.7 & 12.0 \\
\hline \multirow[t]{3}{*}{ BM } & 2 & $2-0-0$ & 4.5 & 0.8 & 15.0 \\
\hline & 3 & $3-2-1$ & 17.0 & 6.8 & 40.0 \\
\hline & 1 & $2-1-0$ & 6.8 & 1.8 & 17.0 \\
\hline \multirow[t]{3}{*}{ BO } & 2 & $2-1-0$ & 6.8 & 1.8 & 17.0 \\
\hline & 3 & $2-1-1$ & 9.2 & 3.4 & 22.0 \\
\hline & 1 & $3-0-0$ & 7.8 & 2.1 & 22.0 \\
\hline \multirow[t]{3}{*}{$\mathrm{CM}$} & 2 & $3-1-0$ & 11.0 & 3.5 & 26.0 \\
\hline & 3 & $4-3-2$ & 39.0 & 14.0 & 100.0 \\
\hline & 1 & $3-1-0$ & 11.0 & 3.5 & 26.0 \\
\hline \multirow[t]{3}{*}{$\mathrm{CO}$} & 2 & $3-1-1$ & 14.0 & 5.6 & 36.0 \\
\hline & 3 & $5-3-2$ & 140.0 & 52.0 & 400.0 \\
\hline & 1 & $2-0-0$ & 4.5 & 0.8 & 15.0 \\
\hline \multirow[t]{3}{*}{ FM } & 2 & $2-0-0$ & 4.5 & 0.8 & 15.0 \\
\hline & 3 & $3-2-2$ & 20.0 & 6.8 & 40.0 \\
\hline & 1 & $0-0-0$ & $<1.8$ & - & 6.8 \\
\hline \multirow[t]{3}{*}{ FO } & 2 & $2-1-0$ & 6.8 & 1.8 & 17.0 \\
\hline & 3 & $3-2-2$ & 20.0 & 6.8 & 40.0 \\
\hline & 1 & $1-1-0$ & 4.0 & 0.7 & 12.0 \\
\hline \multirow[t]{3}{*}{ UM } & 2 & $2-1-0$ & 6.8 & 1.8 & 17.0 \\
\hline & 3 & $2-1-1$ & 9.2 & 3.4 & 22.0 \\
\hline & 1 & $1-1-0$ & 4.0 & 0.7 & 12.0 \\
\hline \multirow[t]{2}{*}{ vo } & 2 & $2-0-0$ & 4.5 & 0.8 & 15.0 \\
\hline & 3 & $3-2-1$ & 17.0 & 6.8 & 40.0 \\
\hline
\end{tabular}

FM, BM, UM and CM are the mineral solutions of Furlani (1995), Bernardes (1997), Ueda (1990) and Castellane and Araújo (1994), respectively; FO, BO, UO and CO are the modified solutions of Furlani (1995), Bernardes (1997), Ueda (1990), and Castellane and Araújo (1994), respectively.

Table 2. Microbiological parameters analyzed in the stock nutrient solutions and tank water used to prepare the solutions.

\begin{tabular}{|c|c|c|c|c|c|c|}
\hline \multirow{2}{*}{ Solution } & \multicolumn{2}{|l|}{ Total coliforms ${ }^{-1}\left(35^{\circ} \mathrm{C}\right)$} & \multicolumn{3}{|c|}{ Thermotolerant coliforms $\left(45^{\circ} \mathrm{C}\right)$} & \multirow{2}{*}{ Salmonella spp } \\
\hline & Combination of tubes & MPN $100 \mathrm{~mL}^{-1}$ & Eombination of tubes & MPN $100 \mathrm{~mL}^{-1}$ & & \\
\hline$\overline{\mathrm{BM}}$ & $5-3-3$ & 170 & $4-1-0$ & 17 & - & - \\
\hline 30 & $5-5-5$ & 1600 & $3-2-0$ & 14.0 & . & - \\
\hline zM & $4-1-1$ & 21 & $3-1-1$ & 14 & . & - \\
\hline 20 & $5-5-5$ & 1600 & $1-1-0$ & 4 & . & - \\
\hline FM & $5-2-1$ & 70 & $3-0-0$ & 7.8 & . & - \\
\hline FO & $5-5-5$ & 1600 & $3-2-0$ & 14 & . & - \\
\hline UM & $5-3-3$ & 170 & $3-0-0$ & 1.8 & . & - \\
\hline Jo & $5-5-5$ & 1600 & $2-0-0$ & 10.0 & . & - \\
\hline Tank water & $5-5-5$ & 1600 & $7-2-2$ & 32 & Present & Present \\
\hline
\end{tabular}

FM, BM, UM and CM are the mineral nutrient solutions of Furlani (1995), Bernardes (1997), Ueda (1990) and Castellane and Araújo (1994), respectively; FO, BO, UO and CO are the modified solutions of Furlani (1995), Bernardes (1997), Ueda (1990), and Castellane and Araújo (1994), respectively.

Table 3. Most probable number (MPN) of thermotolerant coliforms in curly lettuce.

\begin{tabular}{|c|c|c|c|c|c|}
\hline \multirow{2}{*}{ Nutrient solutions } & \multirow{2}{*}{ Samples } & \multirow{2}{*}{ Combination of Tubes +} & \multirow{2}{*}{$M P N g^{-1}$} & \multicolumn{2}{|c|}{ Confidence interval (95\%) } \\
\hline & & & & Minimum & Maximum \\
\hline \multirow{3}{*}{ BM } & 1 & $0-0-0$ & $<1.8$ & - & 6.8 \\
\hline & 2 & $0-0-0$ & $<1.8$ & - & 6.8 \\
\hline & 3 & $1-1-0$ & 4.0 & 0.7 & 12.0 \\
\hline \multirow{3}{*}{ BO } & 1 & $1-0-0$ & 2.0 & 0.1 & 10.0 \\
\hline & 2 & $1-1-0$ & 4.0 & 0.7 & 12.0 \\
\hline & 3 & $2-1-0$ & 6.8 & 1.8 & 17.0 \\
\hline \multirow{3}{*}{$\mathrm{CM}$} & 1 & $0-0-0$ & $<1.8$ & - & 6.8 \\
\hline & 2 & $1-0-0$ & 2.0 & 0.1 & 10.0 \\
\hline & 3 & $1-0-0$ & 2.0 & 0.1 & 10.0 \\
\hline \multirow{3}{*}{$\mathrm{CO}$} & 1 & $1-0-0$ & 2.0 & 0.1 & 10.0 \\
\hline & 2 & $2-0-0$ & 4.5 & 0.8 & 15.0 \\
\hline & 3 & $2-1-0$ & 6.8 & 1.8 & 17.0 \\
\hline \multirow{3}{*}{ FM } & 1 & $1-0-0$ & 2.0 & 0.1 & 10.0 \\
\hline & 2 & $1-1-1$ & 6.1 & 1.8 & 15.0 \\
\hline & 3 & $2-0-0$ & 4.5 & 0.8 & 15.0 \\
\hline \multirow{3}{*}{ FO } & 1 & $0-0-0$ & $<1.8$ & - & 6.8 \\
\hline & 2 & $1-0-0$ & 2.0 & 0.1 & 10.0 \\
\hline & 3 & $1-1-0$ & 4.0 & 0.7 & 12.0 \\
\hline \multirow{3}{*}{ UM } & 1 & $1-0-0$ & 2.0 & 0.1 & 10.0 \\
\hline & 2 & $1-0-0$ & 2.0 & 0.1 & 10.0 \\
\hline & 3 & $1-1-0$ & 4.0 & 0.7 & 12.0 \\
\hline \multirow{3}{*}{ UO } & 1 & $0-0-0$ & $<1.8$ & - & 6.8 \\
\hline & 2 & $1-0-0$ & 2.0 & 0.1 & 10.0 \\
\hline & 3 & $1-1-0$ & 4.0 & 0.7 & 12.0 \\
\hline
\end{tabular}

FM, BM, UM and CM are the mineral solutions of Furlani (1995), Bernardes (1997), Ueda (1990) and Castellane and Araújo (1994), respectively; FO, BO, UO and CO are the modified solutions of Furlani (1995), Bernardes (1997), Ueda (1990), and Castellane and Araújo (1994), respectively. 
Table 4. Most probable number (MPN) of Salmonella and Escherichia coli in curly lettuce.

\begin{tabular}{|c|c|c|c|c|c|}
\hline \multirow{2}{*}{ Nutrient solutions } & \multirow{2}{*}{ Samples } & \multirow{2}{*}{ Combination of Tubes +} & \multirow{2}{*}{$\begin{array}{l}\text { Salmonella spp. and E. coli } \\
\text { MPN } 100 \mathrm{~mL}^{-1}\end{array}$} & \multicolumn{2}{|c|}{ Confidence interval (95\%) } \\
\hline & & & & Minimum & Maximum \\
\hline & 1 & $0-0-0$ & $<1.8$ & - & 6.8 \\
\hline \multirow[t]{3}{*}{ BM } & 2 & $0-0-0$ & $<1.8$ & - & 6.8 \\
\hline & 3 & $0-0-0$ & $<1.8$ & - & 6.8 \\
\hline & 1 & $0-0-0$ & $<1.8$ & - & 6.8 \\
\hline \multirow[t]{3}{*}{ BO } & 2 & $0-0-0$ & $<1.8$ & - & 6.8 \\
\hline & 3 & $0-0-0$ & $<1.8$ & - & 6.8 \\
\hline & 1 & $0-0-0$ & $<1.8$ & - & 6.8 \\
\hline \multirow[t]{3}{*}{$\mathrm{CM}$} & 2 & $0-0-0$ & $<1.8$ & - & 6.8 \\
\hline & 3 & $0-0-0$ & $<1.8$ & - & 6.8 \\
\hline & 1 & $0-0-0$ & $<1.8$ & - & 6.8 \\
\hline \multirow[t]{3}{*}{$\mathrm{CO}$} & 2 & $0-0-0$ & $<1.8$ & - & 6.8 \\
\hline & 3 & $0-0-0$ & $<1.8$ & - & 6.8 \\
\hline & 1 & $0-0-0$ & $<1.8$ & - & 6.8 \\
\hline \multirow[t]{3}{*}{ FM } & 2 & $0-0-0$ & $<1.8$ & - & 6.8 \\
\hline & 3 & $0-0-0$ & $<1.8$ & - & 6.8 \\
\hline & 1 & $0-0-0$ & $<1.8$ & - & 6.8 \\
\hline \multirow[t]{3}{*}{ FO } & 2 & $0-0-0$ & $<1.8$ & - & 6.8 \\
\hline & 3 & $0-0-0$ & $<1.8$ & - & 6.8 \\
\hline & 1 & $0-0-0$ & $<1.8$ & - & 6.8 \\
\hline \multirow[t]{3}{*}{ UM } & 2 & $0-0-0$ & $<1.8$ & - & 6.8 \\
\hline & 3 & $0-0-0$ & $<1.8$ & - & 6.8 \\
\hline & 1 & $0-0-0$ & $<1.8$ & - & 6.8 \\
\hline \multirow[t]{2}{*}{ vo } & 2 & $0-0-0$ & $<1.8$ & - & 6.8 \\
\hline & 3 & $0-0-0$ & $<1.8$ & - & 6.8 \\
\hline
\end{tabular}

FM, BM, UM and CM are the mineral solutions of Furlani (1995), Bernardes (1997), Ueda (1990) and Castellane and Araújo (1994), respectively; FO, BO, UO and CO are the modified solutions of Furlani (1995), Bernardes (1997), Ueda (1990), and Castellane and Araújo (1994), respectively.

Table 5. Groups and species of the parasites found in lettuce (Lactuca sativa) as a function of the different nutrient solutions.

\begin{tabular}{|c|c|c|c|c|c|c|c|c|}
\hline \multirow{3}{*}{ Nutrient solutions } & \multirow{3}{*}{ Samples } & \multicolumn{7}{|c|}{ Group } \\
\hline & & \multirow{2}{*}{\multicolumn{2}{|c|}{$\begin{array}{ll}-- \text { Protozoa-- } & -- \\
\text { A } & \text { B }\end{array}$}} & \multicolumn{3}{|c|}{ - } & \multirow[b]{2}{*}{$\mathrm{F}$} & \multirow[b]{2}{*}{ G } \\
\hline & & & & $\mathrm{C}$ & $\mathrm{D}$ & $E$ & & \\
\hline \multirow{3}{*}{ BM } & 1 & - & - & - & - & - & - & - \\
\hline & 2 & - & - & - & + & - & - & - \\
\hline & 3 & - & - & - & - & - & - & - \\
\hline \multirow{3}{*}{ BO } & 1 & - & - & - & + & - & - & - \\
\hline & 2 & - & - & - & - & - & - & - \\
\hline & 3 & - & - & - & - & - & - & - \\
\hline \multirow{3}{*}{ FM } & 1 & - & - & - & - & - & - & - \\
\hline & 2 & - & - & - & - & - & - & - \\
\hline & 3 & - & - & - & - & - & - & - \\
\hline \multirow{3}{*}{ FO } & 1 & - & - & - & - & - & - & - \\
\hline & 2 & - & - & - & - & - & - & - \\
\hline & 3 & - & - & - & - & - & - & - \\
\hline \multirow{3}{*}{$\mathrm{CM}$} & 1 & - & - & - & - & - & - & - \\
\hline & 2 & - & - & - & - & - & - & - \\
\hline & 3 & - & - & - & - & - & - & - \\
\hline \multirow{3}{*}{$\mathrm{CO}$} & 1 & + & - & - & + & - & - & - \\
\hline & 2 & - & - & - & + & - & + & - \\
\hline & 3 & - & - & - & - & - & - & - \\
\hline \multirow{3}{*}{ UM } & 1 & - & - & - & - & - & - & - \\
\hline & 2 & + & - & - & - & - & - & - \\
\hline & 3 & - & - & - & + & - & + & - \\
\hline \multirow{3}{*}{ UO } & 1 & - & - & - & - & - & - & - \\
\hline & 2 & - & - & - & + & - & - & - \\
\hline & 3 & - & - & - & - & - & - & - \\
\hline
\end{tabular}

A - Entamoeba histolytica, B - Giardia lamblia, C - Taenia sp., D - Eggs of Ancylostoma sp., E - Eggs of Ascaris -lumbricoides, F - Filarial larva of Ancylostoma and G - Schistosoma mansoni. (+) presence and (-) absence. FM, BM, UM and CM are the mineral solutions of Furlani (1995), Bernardes (1997), Ueda (1990) and Castellane and Araújo (1994), respectively; FO, BO, UO and CO are the modified solutions of Furlani (1995), Bernardes (1997), Ueda (1990), and Castellane and Araújo (1994), respectively.

Studies demonstrate that the microbial contamination of the crops is lower in hydroponic system. Authors such as Tonet et al. (2011), evaluating lettuce cultivation in hydroponic and aquaponic systems, observed that, despite the existence of thermotolerant coliforms in the water used in the production process, the results are within the standards for consumption stipulated by the current legislation. Rios (2008), studying the utilization of yellow waters (human urine) with contamination by fecal coliforms above 1100 MPN $100 \mathrm{~mL}^{-1}$ in lettuce hydroponic cultivation, also harvested plants within the acceptable standards for consumption.
The presence of thermotolerant coliforms in vegetables is worrisome because they are consumed raw. Thermotolerant coliforms are bacteria that indicate fecal contamination, which is confirmed by the presence of $E$. coli. The presence of this microorganism results from contamination by feces of homeothermic animals or domestic sewage and, therefore, it may be indicating the presence of pathogenic microorganisms transmitted through water and food that can favor the occurrence of severe infectious diseases such as cholera, salmonellosis, shigellosis and hepatitis, among others. 


\section{Contamination by E. coli and Salmonella}

In the present study, regardless of the utilized solution, the analyzed curly lettuce samples do not pose any risk to the health of the consumer regarding the presence of $E$. coli and Salmonella (Table 4). The absence of these microorganisms in the lettuce plants is an indication that the hydroponic profiles can work as a physical barrier to prevent the contact of the edible part of the plants with the effluent used in the nutrient solution.

The hydroponic system used in the present study, despite being in a protected environment, is not free from possible fecal contaminations from warm-blooded animals, such as birds, rodents and even humans. However, the incidence would be small and would not occur regularly. For organomineral solution, the entry of coliforms in the system is diluted in the water used in its preparation. Normally, in hydroponic systems, the leaves do not come into contact with the solution, but there may be splashes of solution and contaminated water on the leaves, and consequently, their contamination.

Absence of Salmonella spp. in hydroponic lettuce has been reported in various studies. Faria et al. (2005) did not detect this microorganism in any sample of lettuce harvested in conventional and hydroponic systems. Santana et al. (2006) also reported absence of Salmonella in lettuce from hydroponic system.

\section{Parasitological contamination}

The obtained results for parasitological contamination are presented in Table 5. From the seven types of parasites found in the tank water and modified solutions, only three were found in the lettuce samples: Entamoeba histolytica, eggs of Ancylostoma and larvae of Ancylostoma (Table 5).

According to Table 5, in all analyzed samples, the presence of the protozoan Entamoeba histolytica occurred with frequency of $8.33 \%$, using the solutions CO and UM. This contamination is associated with the organic ingredients used to prepare the organomineral solution (modified) and with the contamination present in the tank water. This value is lower than that reported by Neres et al. (2011), who found $12.19 \%$ of contamination by Entamoeba histolytica in hydroponic lettuce. According to some authors, lettuce contamination by Entamoeba histolytica can be even higher when there is inadequate post-harvest handling of the product. According to Oliveira et al. (2012), in the market of Ipatinga, MG, $60 \%$ of the samples are contaminated. Pereira et al. (2012), conducting a study in supermarkets and public markets of João Pessoa, PB, observed contamination of 30 and $44 \%$, respectively.

Salmonella and Entamoeba histolytica are frequent in food outbreaks and can compromise human health, according to the Resolution no 12/2001 of ANVISA (2001); in vegetable quality evaluation, these two microorganisms must be absent in 25-g food samples.

With respect to the presence of helminths, eggs of Ancylostoma were found in lettuce plants fertigated with the solutions $\mathrm{BM}, \mathrm{BO}, \mathrm{CO}, \mathrm{UM}$ and $\mathrm{UO}$, and filarial larvae with the utilization of $\mathrm{CO}$ and $\mathrm{UM}$, which corresponded to frequencies of $25 \%$ and $8.33 \%$ of the analyzed samples, respectively. The contamination originated from mineral and modified solutions once again evidences the contribution of the tank water to these results.

Santana et al. (2006) also found contamination of hydroponic lettuce by Ancylostoma in $26.7 \%$ of the analyzed samples. In a study conducted in the market of Cuiabá, MT, Alves et al. (2013) found $18.7 \%$ of contaminated samples, while Oliveira and Peres (2014) observed contamination by Ancylostoma in $37 \%$ of the analyzed lettuce samples in the municipality of Foz do Iguaçu, PR.

The low levels of microbiological and parasitological contamination observed in the present study are encouraging, especially regarding the utilization of organomineral solutions in hydroponic systems. Based on Table 2, it is noted that the water used to prepare the nutrient solutions showed higher contamination, compared with the stock nutrient solutions. It should be highlighted that, during the conduction of the experiment, the nutrient solutions were daily calibrated and adjusted for 24 days (Supplementary Table 1). In this period, the replenished water volumes were $33.23,30.19,33.68,24.86$, 35.13, 19.0, 31.8 and $29.8 \mathrm{~L}$, while the volume of nutrient solutions were 29.92, 21.86, 36.57, 10.36, 15.48, 78.92, 22.51 and $17.37 \mathrm{~L}$ for the solutions FM, FO, BM, BO, UM, UO, CM and CO, respectively. This means that, during all the experiment, a significant load of pathogenic microorganisms was also added to the hydroponic system. Absence of E. Coli, Salmonella and most parasitoids in the lettuce samples presupposes that the change of environment of the tank water to form the nutrient solutions reduced their contaminating action, because the solutions were aerated during the biodegradation process and when they supplied the gutters. There was an increment of mineral fertilizers in all solutions (mineral and organomineral) and acids and bases for $\mathrm{pH}$ correction. According to Pachepsky et al. (2011), various factors can influence the survival and proliferation of microorganisms in the water, including temperature, competing microorganisms, $\mathrm{pH}$, quality and availability of nutrients, solar radiation, among others.

\section{Materials and methods}

\section{Experiment location and conduction}

The experiment was carried out in hydroponic system adopting the nutrient film technique (NFT), in protected environment (greenhouse), at the Center of Agricultural and Environmental Sciences (CCAA), of the State University of Paraíba (UEPB), situated in the city of Lagoa Seca, Paraíba, at the following geographic coordinates: $7^{\circ} 10^{\prime} 15^{\prime \prime} \mathrm{S}, 35^{\circ} 51^{\prime}$ $14^{\prime \prime} \mathrm{W}$. According to the Köppen-Geige climatic classification (Brasil, 1971), the climate of the municipality is characterized as humid tropical (As'), with mean annual temperature around $22 \stackrel{\circ}{ } \mathrm{C}$, minimum of $18 \stackrel{\circ}{\circ}$ and maximum of $33^{\circ} \mathrm{C}$.

\section{Preparation of the nutrient solutions}

Treatments consisted of eight nutrient solutions; four with chemical compositions proposed by Bernardes (1997), Castellane and Araújo (1994), Furlani (1995) and Ueda (1990), called BM, CM, FM and UM, respectively, and four with chemical compositions similar to those previously cited, modified in the present research with the utilization of 
biofertilizer in the composition, producing four organomineral nutrient solutions, which were referred to as modified nutrient solutions of Bernardes (1997) (BO), Castellane and Araújo (1994) (CO), Furlani (1995) (FO) and Ueda (1990) (UO). The experiment was carried out in randomized blocks with three replicates; each plot had two gutters spaced by $0.30 \mathrm{~m}$; each gutter contained 10 curly lettuce plants, spaced by $0.30 \mathrm{~m}$. The chemical composition of the mineral solutions is described in Supplementary Table 2.

The modified solutions were prepared by initially formulating four biofertilizers with the SOLVER tool of Microsoft Office Excel, to obtain a mixture of organic ingredients with chemical composition similar to those suggested by Ueda (1990), Castellane and Araújo (1994), Furlani (1995) and Bernardes (1997); these biofertilizers were called $\mathrm{BIO} 1, \mathrm{BIO} 2, \mathrm{BIO} 3$ and $\mathrm{BIO} 4$, respectively. The utilized ingredients were bovine manure, bovine milk and poultry blood from the CCAA/UEPB and molasses purchased in the market of Campina Grande, Paraíba. The chemical characterization and quantities of the ingredients used in the preparation of these biofertilizers are presented in Supplementary Tables 3 and 4, respectively.

After formulation, the ingredients were mixed and diluted in $30 \mathrm{~L}$ of tank water (rainwater) with the following chemical composition: $0.239 \mathrm{dS} \mathrm{m}{ }^{-1} ; \mathrm{pH}=7.3$ and in $\mathrm{mg} \mathrm{L}^{-1}: \mathrm{Ca}^{++}$ hardness $=48.4 ; \mathrm{Mg}^{++}$hardness $=6.4$; total hardness $\left(\mathrm{CaCO}_{3}\right)$ $=147.5 ; \mathrm{K}^{+}=21.7 ; \mathrm{Cl}^{-}=33.4 ; \mathrm{Na}^{+}=4.7 ;$ total $\mathrm{Fe}=0.01 ; \mathrm{SO}_{4}{ }^{-}=$ 3.3; $\mathrm{P}=0.0 ; \mathrm{NO}_{3}{ }^{-}=0.75$ and $\mathrm{NH}_{4}{ }^{+}=0.15$. Subsequently, the biofertilizers underwent biodegradation for 30 days with the aid of an air compressor, at intervals of $15 \mathrm{~min}$, which ensured a dissolved oxygen concentration close to $2.0 \mathrm{mg} \mathrm{L}^{-1}$ and, consequently, the action of aerobic microorganisms. Once matured, samples of the biofertilizers were collected and chemically characterized based on dry weight, in the Laboratory of Soil, Water and Plant Analysis of the Agricultural Research Company of Rio Grande do Norte EMPARN. The results are described in Supplementary Table 5.

Since the chemical characterization of the biofertilizers showed nutritional concentration lower than those recommended by Ueda (1990), Castellane and Araújo (1994), Furlani (1995) and Bernardes (1997) (Table 7), these biofertilizers needed to be complemented with mineral fertilizers. The quantities of the biofertilizers used to prepare $360 \mathrm{~L}$ of mineral and modified stock solutions are presented in Supplementary Table 6.

\section{Lettuce planting and calibration of the nutrient solutions}

Curly lettuce seedlings were produced in phenolic foam, by sowing one pelleted seed per hole. After seedling emergence (SE), the tank water used for irrigation was gradually substituted by the nutrient solutions (33.33\%, $66.66 \%$ and $100 \%$ every four days). After 16 days from SE, seedlings were transplanted to the definitive profiles.

The nutrient solutions supplying the gutters were daily calibrated through the addition of tank water and nutrient solution according to the treatments, in order to maintain the volume of $17 \mathrm{~L}$ in the tank, electrical conductivity of 1.5 $\mathrm{dS} \mathrm{m}^{-1}$ and $\mathrm{pH}$ close to neutrality, using a solution of $\mathrm{NaOH}$ or $\mathrm{H}_{2} \mathrm{SO}_{4}\left(1 \mathrm{~mol} \mathrm{~L} \mathrm{~L}^{-1}\right)$. Supplementary Table 1 shows the volumes of supply water and stock nutrient solutions daily replenished during the twenty-four days after transplanting, period that comprehended the experiment.

\section{Collection and microbiological and parasitological analyses} of lettuce, tank water and stock nutrient solutions

Composite samples of curly lettuce, formed by ten plants per plot, were prepared according to the treatments and replicates under aseptic conditions. The samples were placed in sterilized zip plastic bags. The material was analyzed at the Laboratory of Food Microbiology, UEPB CCAA, following the official method approved by the Association of Official Analytical Chemists - AOAC (2002), for total coliforms at 35 oC, thermotolerant coliforms at 45 으 and E. coli, using the technique of multiple tubes. Parasitological analysis was performed according to the adapted method of Bastos et al. (2002) and Guimarães et al. (2003). Analyses were also made in the tank water used to prepare the solutions and stock solutions that supplied the hydroponic system. The results were compared with the limits established in the Resolutions RDC 12/2001 (ANVISA, 2001) and 357/2005 (CONAMA, 2005).

The methodology employed in the parasitological analysis is similar to the widely-known method of Hoffmann et al. (1934), used in clinical analyses, and this method is an adaptation of those described by Bastos et al. (2002) and Guimarães et al. (2003).

The eggs and cysts of the parasites found in the tank water sample and modified solutions were: egg of Ancylostoma, egg of Schistosoma mansoni, egg of Ascaris, egg of Taenia spp., cyst of Giardia lamblia, cyst of Entamoeba histolytica and larva of Ancylostoma.

The methodology employed in the parasitological analysis is similar to the widely-known method of Hoffmann et al. (1934), used in clinical analyses, and this method is an adaptation of those described by Bastos et al. (2002) and Guimarães et al. (2003).

\section{Conclusion}

Regardless of the utilized nutrient solution, the analyzed samples of curly lettuce were free from contamination by $E$. coli and Salmonella, meeting the standards established by the National Health Surveillance Agency - ANVISA. Lettuce plants showed low parasitological contamination; there was only presence of cysts of Entamoeba histolytica, eggs and larvae of Ancylostoma sp., only in some nutrient solutions. The use of organomineral solutions is viable in hydroponic systems, being recommended for regions that use lowquality irrigation water in the production of vegetables.

\section{Acknowledgments}

The authors thank the State University of Paraíba, for its contribution through the PROPESQ program to conduct this research.

\section{References}

Alves AS, Cunha Neto AE, Paulo AR (2013) Parasitos em alfacecrespa (lactuca sativa I.), de plantio convencional, comercializada em supermercados de Cuiabá, Mato Grosso, Brasil. Rev Patolog Trop. 42: 217-229. 
ANVISA (2001) Ministério da Saúde. Secretária Nacional de Vigilância Sanitária. Resolução no 12, de 2 de janeiro de 2001. Dispõe sobre padrões microbiológicos. Diário Oficial da República Federativa do Brasil. Brasília (DF), 10 jan. 2001. Seção I, p. 48.

Arbos KA, Freitas RJS, Stertz SC, Carvalho LA (2010) Segurança alimentar de hortaliças orgânicas: aspectos sanitários e nutricionais. Ciên Tecnol Aliment 30: 215-220.

AOAC (2002) Association of Official Analytical Chemists Official methods of analysis of AOAC international. Washington.

Barros AJM, Ceballos BSO, König A, Gheyi HR (1999) Avaliação sanitária e físico-química das águas para irrigação de hortaliças no agreste e brejo paraibanos. Rev Bras Eng Agríc Ambient. 3: 355360.

Bastos RKX, Neves C, Bevilacqua PD, Silva CV, Carvalho GRM (2002) Avaliação da contaminação de hortaliças irrigadas com esgotos sanitários. Rev Aidis. 1:1-8.

Baumgartner D, Sampaio SC, Silva TR, Teo CRPA, Boas MAV (2007) Reúso de águas residuárias da piscicultura e da suinocultura na irrigação da cultura da alface. Eng Agríc. 27: 152-163.

Bernardes LHH (1997) Hidroponia da alface: uma história de sucesso. São Paulo, Estação Experimental de Hidroponia "Alface e Cia".

Brasil (1971) Ministério da Agricultura. Equipe de Pedologia e Fertilidade do Solo.. Levantamento exploratório. Reconhecimento de solos do estado da Paraíba. Rio de Janeiro, SUDENE, 670p. (Boletim Técnico, 15).

Castellane PD, Araújo JAC (1994) Cultivo sem solo: hidroponia Jaboticabal, FUNEP.

CONAMA (2005) Conselho Nacional do Meio Ambiente Resolução n.o 357, de 17 de março de 2005. Diário Oficial da República Federativa do Brasil, Brasília.

Dias BCO, Gazzinelli SEP (2014) Verificação e identificação de formas parasitárias em culturas de alface (Lactuca sativa) na Estância Turística de São Roque. Sci Vitae. 1: 27-34.

Faria MI, Falcão CAC, Tórtora JCO (2005) Contaminação microbiana e melhoria do sistema produtivo de alfaces (Lactuca sativa), de cultivo tradicional e hidropônico, no Rio de Janeiro. Higi Aliment. 19: 104- 109,

Filgueira FAR (2008) Novo manual de olericultura: agrotecnologia moderna na produção e comercialização de hortaliças. Viçosa, UFV.

Ferreira AP, Horta MAP, Pereira CRA (2013) Qualidade higiênicosanitária das águas de irrigação de estabelecimentos produtores de hortaliças no município de Teresópolis, RJ. Rev Uniandrade. 13: 15-29.

Finatto J, Altmayer T, Martini MC, Rodrigues M, Basso V, Hoehne L (2013) A importância da utilização da adubação orgânica na agricultura. Rev Destaques Acad. 5: 85-93.

Furlani PR (1995) Cultivo de alface pela técnica de hidroponia - NFT. Campinas, IAC, 18p. (IAC Documentos 55).

Guimarães AM, Alves EGL, Figueiredo HCP, Costa GM, Rodrigues LS (2003) Freqüência de enteroparasitas em amostras de alface (Lactuca sativa) comercializada em Lavras, Minas Gerais. Rev Soc Bras Med Trop. 36: 621-623.

Henz GP, Suinaga F (2009) Tipos de alface cultivados no Brasil. Brasilia: Embrapa hortaliças, 7p (Emprapa hortaliças, Comunicado Técnico 75).

Hoffman WA, Pons JA, Janer JL (1934) Sedimentation concentration method in Schistosomiasis mansoni. Int JTrop Med Public Health. 9:283-289.

Hollyer J,Tamaru C, Riggs A, Klinger-Bowen RE, Howerton R, Okimoto D, Castro L, Ron TB, Fox BK, Troegner V, Martinez G (2009) On-Farm Food Safety: Aquaponics. Food Safety Tech. 38: 18.
IBGE - Instituto Brasileiro de Geografia e Estatística (2009) Censo Agropecuário 2006. Brasil, Grandes Regiões e Unidades da Federação. Rio de Janeiro: IBGE, 777 p.

Itohan AM, Peters O, Kolo I (2011) Bacterial contaminants of salad vegetables in Abuja Municipal Area Concil, Nigeria. Malays J Microbiol. 7: 111-114.

Lima SM, Henrique IN, Ceballos BSO, Souza JT, Araújo HWC (2005) Qualidade sanitária e produção de alface irrigada com esgoto doméstico tratado. Rev Bras Eng Agrí Ambient. 9: 21-25.

Moretti CL, Mattos LM (2005) Processamento mínimo de alface crespa. Brasília: Embrapa hortaliças, 7p. (Emprapa hortaliças, Comunicado Técnico 36).

Neres AC, Nascimento $A H$, Lemos KRM, Ribeiro EL, Leitão VO, Pacheco JBP, Diniz DO, Aversi-Ferreira RAGMF, Aversi-Ferreira TL (2011) Enteroparasitos em amostras de Alface (Lactuca sativa var. crespa), no município de Anápolis, Goiás, Brasil. Biosci J. 27: 336341.

Oliveira AAB, Perez LF (2014) Contaminação de enteroparasitas em folhas de alface (Lactuca sativa) e agrião (Nasturtium officinalis) em duas hortas comerciais de foz do iguaçu, Estado do Paraná, Brasil. Rev Eletr Novo Enfoque. 18: 109-124.

Oliveira DCS, Brito JK, Maia MC (2012) Avaliação parasitológica em amostras de alfaces (Lactuca sativa) Comercializadas em supermercados de Ipatinga, Minas Gerais. Nutrir Gerais. 6: 933944.

Pachepsky Y, Shelton DR, Mclain JET, Patel J, Mandrell, RE (2011) Irrigation Waters as a Source of Pathogenic Microorganisms in Produce: A Review. Acad Press. 113: p. 73-138.

Pereira JA, Freitas FIS, Maciel JF (2012) Qualidade microbiológica da alface (lactuca sativa) comercializada em João Pessoa-PB. Rev Bio Farm. 8: 125-130.

Rios ECSV (2008) Uso de águas amarelas como fonte alternativa de nutriente em cultivo hidropônico da alface (Lactuca sativa). $85 \mathrm{f}$ Dissertação (Mestrado em Engenharia Ambiental). Universidade Federal do Espirito Santo (UFES), Vitória, Espirito Santo.

Rocha A, Mendes RA, Barbosa CS (2008) Strongyloides spp. e outros parasitos encontrados em alfaces (Lactuca sativa) comercializados na cidade do Recife, PE. Rev Patol Trop. 37: 151-160.

Santana LRR, Carvalho RDS, Leite CC, Alcântara LM, Oliveira TWS, Rodrigues BM (2006) Qualidade física, microbiológica e parasitológica de alfaces (lactuca sativa) de diferentes sistemas de cultivo. Ciên Tecnol Aliment. 26: 264-269.

Santos CMG, Braga CL, Vieira MRS, Cerqueira, R, Brauer RL, Lima GPP (2010) Qualidade da alface comercializada no município de Botucatu-SP. Rev Iber Tecnol Postcosecha. 11: 67-74.

Santos GD, Peixoto MSRM (2007) Detecção de estruturas de enteroparasitas em amostras de alfaces (Lactuva sativa) comercializadas em Campina Grande, PB. Rev News Lab. 80: 142 150.

Souto RA (2005) Avaliação sanitária da água de irrigação e de alfaces (Lactuca sativa L.) produzidas no município de Lagoa Seca, Paraíba. 70f. Dissertação (Mestrado em Agronomia). Universidade Federal da Paraíba (UFPB), Areia, Paraíba.

Tavella LB, Salino AJS, Campo PA, Sebastião Neto EA, Ferreira RLF (2012) Aplicação foliar de produtos agroecológicos no desempenho agronômico da alface. Agropec Cient Semiarido. 8: 23-27.

Tonet A, Ribeiro AB, Bagatin AM, Quenehenn A, Suzuki CCLF (2011) Análise microbiológica da água e da alface (lactuca sativa) cultivada em sistema aquapônico, hidropônico e em solo. Rev Bras Pesq Aliment. 2: 83-88.

Ueda S (1990) Hidroponia: guia prático. São Paulo, Agroestufa. 